\title{
The Correlation Between Transformational Leadership Characteristics of School Administrators and School Safety*
}

\author{
Mevsim Zengin ${ }^{1}$, Durdağı Akan $^{2}$ \\ ${ }^{1}$ MEB, Mersin, Turkey \\ ${ }^{2}$ Faculty of Education, Atatürk University, Erzurum, Turkey. \\ Correspondence: Mevsim Zengin, MEB, Mersin, Turkey.
}

Received: September 12, 2019

Accepted: October 7, $2019 \quad$ Online Published: October 8, 2019

doi:10.11114/jets.v7i11.4519

URL: https://doi.org/10.11114/jets.v7i11.4519

\begin{abstract}
This study attempts to comparatively explore the correlation between transformational leadership characteristics of school administrators and school safety in teachers' views. The sample of the research with a survey model consists of a total of 744 teachers employed in the central districts of the province of Mersin. In the research, the "Transformational Leadership Scale" and the "School Safety Scale" are incorporated as data gathering instruments. Arithmetic mean, standard deviation, pearson's product-moment correlation and multiple linear regression analysis technique are employed for the analysis of the data obtained from the study. It has been concluded that the transformational leadership characteristics of the participant school administrators are significant predictors of school safety in the participant teachers' views.
\end{abstract}

Keywords: leadership, transformational leadership, school safety, principals, teacher

\section{Introduction}

As in all social systems, organisations are forced to constantly develop and update. There is a need for change to exist and survive; there is a need for transformation to advance and rise (Zeren, 2007). There has been a transformative change in society and transformative leaders are guiding and pioneering this process (Çelik, 1998). In organisations, leader question existing operations as part of their transforming process and to create a common vision (Çelik, 2010; Çobanoğlu, 2003; Eryılmaz, 2006; Karip, 1998; Zeren, 2007). Under current settings where intense and rapid transformations are the norm, it is impossible to meet the changing world with a traditional management approach. In this process, there is the need for a new type of leadership such as transformational leadership.

Transformational leaders are the expected heroes of hard times (Aydoğmuş, 2004) provide organizational energy based on organizational objectives by shaping employee's expectations, energy, needs, and objectives to create a coordinated, assured and collective consciousness. Thus, it is possible to both increase employee satisfaction, satisfaction, quality of life in the organization, and organizational loyalty and also create synergies to realise organizational purposes (Akan \& Yalçın, 2015). Charismatic leadership, as the most important element of transformational leadership, (Eryılmaz, 2006; Karip, 1998; Serinkan, 2003) exhibits influence and guides properties to audiences (Serinkan, 2003). This way organisational links between employees strengthen and the level of dedication to the organisational increases.

Transformational leaders who are free from the fear of losing power and authority (Murat and Açıkgöz, 2008) are individuals who ensure a group or a society to move toward a common purpose rather than individual purposes (Robbins \& DeCenzo, 1998) and they are visionary practitioners of the future (Cömert, 2004), courageous and unyielding (Berber, 2000), and inspiring (Erkunt, 2015). In short, these are individuals who ensure transformational activities (Temel, 2016). Colvin (1998) expressed that majority of authors define transformational leadership as shaping culture, being a role-model, and possessing instructive, reliable and courageous traits. However, according to Bass (1985), such leadership can be defined as increasing employee awareness, persuading others on the need for development, express efforts to advance, and having a high performance, and by uncovering belief and dedication in organisation (Transferred by: Şahin, 2004).

\footnotetext{
${ }^{*}$ This article has been prepared by using doctoral thesis.
} 
Under the modern education management paradigm, schools are considered as "transforming organisations" and principles are considered as "transformational leaders" (Keleş, 2009). Transformational leadership behaviour has an important role to monitor technological and scientific developments at schools, fitting into changing environmental conditions and increasing educational quality (Çelik, 2010). School principals as transformational leader convince teachers for the need to transform and motive them to create a learning school (Erylmaz, 2006). Schools are complex human organisations that combine students, teachers, instruction assistants, counselors, psychologists, social workers, nurses, support personnel, management, parents and other components of the society (Astor, Guerra and Acker, 2010). Creating a safe and non-violent school environment is the most fundamental mission of education (Furlong \& Green, 2005). Schools face certain disruptive and anti-social challenges. Such student behaviours intervene with teachers' burn-out and students' learning time (Osher, Bear, Sprague \& Doyle, 2010). Ögel, Tarı and Eke (2005) stated that a safe school is a coherent school. To achieve efficiency in education and training, it is important to keep schools away from danger and ensure their safety. If this does not happen, the educational environment, students and families, and the society will be negatively affected (Posluoğlu, 2014). According to Memduhoğlu and Taşdan (2008) the problem of violence covers a large area in school security. Such that when we talk about school security, we only think about violent acts in schools. Therefore, the phenomenon of violence should be eliminated from school environment and a safe school environment should be created.

In recent years, teachers' and students' safety has been a major concern due to increased violence in schools. School environment is considered as a traditional shelter to protect children from the violence and torment of the outside world. School-based violence and ineffective discipline practices will delay the education process as these lead to on-going fear for teachers and students. Teacher and student learning is impossible in unsafe schools. Academic success is the basis in safe school (Mestry, 2015). Ensuring personnel and students safety at schools is extremely important for effective and efficient education process and to achieve high student performance. In unsafe environments, education and training can fail as there will be safety concerns for both students and teachers. To avoid such issues, school safety should be provided to ensure teachers and students focus on their main objectives. Thus, teachers and students without a concern for safety will show higher performance (Posluoğlu, 2014).

Numerous researchers listed various properties in terms of safe school environment (Bucher \& Manning, 2005; Mayer \& Leone, 1999; Peterson \& Skiba, 2001). These properties can be listed as: Positive and supportive school climate, quality academic teaching; student and parent inclusion in planning and policy making decisions of the school; using fewer coercive precautions that result in insecurity, anxiety and sadness; providing counselling services; preventing violence; solving conflicts and having crisis plans and programs; peer mediation and preventive programs with conflict solution techniques; environmental design and technological inventions; integrating inventions that can contribute to student and instructor safety; ensuring school safety and developing a written plan to prevent violence. Based on this fact, it is possible to say that a positive school climate and constructive communication network has significant contribution to school safety. Simple but practical steps must be realised to have long-term effective solutions to the safety problems observed in almost all schools and to encourage students to focus on their success in positive and living school environment that is far from dangers.

This study aims to determine and analyse the relationship between school principals' transformational leadership properties and the level of school safety. For this purpose, this study investigates answers for following questions based on secondary education teachers' perceptions:

1. What is the level of school principals' transformational leadership properties?

2. What is the level of school safety?

3. Is there a significant relationship between school principals' transformational leadership properties and school safety?

4. Are transformational leadership levels of school principals a significant predictor of school safety?

\section{Method}

\subsection{Study Model, Universe and Sample}

The target universe of this study that adopts a descriptive survey model was secondary school teachers in Mersin city, central province. The research sample consisted in total of 744 teachers working in these schools. Teachers in the sample group were selected randomly with a cluster sampling method. Accordingly, the survey was applied to all teachers in cluster school. Schools were selected from areas with different developmental levels. Gender, branch, and seniority distribution of teachers in the study sample group are given in Table 1. 
Table 1. Personal variable data

\begin{tabular}{llll}
\hline Teachers' Personal Properties & $\mathrm{N}$ & $\%$ \\
\hline Gender & Female & 390 & 52.4 \\
\cline { 2 - 4 } & Male & 354 & 47.6 \\
\cline { 2 - 4 } & Total & 744 & 100 \\
\hline Education Level & Undergraduate & 641 & 86.2 \\
\cline { 2 - 4 } & Graduate & 103 & 13.8 \\
\cline { 2 - 4 } Seniority & Total & 744 & 100 \\
\cline { 2 - 4 } & $0-5$ & 97 & 13 \\
\cline { 2 - 4 } & $6-10$ & 104 & 14 \\
\cline { 2 - 4 } & $11-15$ & 92 & 12.4 \\
\cline { 2 - 4 } & $16-20$ & 22.4 \\
\cline { 2 - 4 } & 21 and higher & 284 & 38.2 \\
\cline { 2 - 4 } & Total & 744 & 100 \\
\hline
\end{tabular}

According to Table 1, the majority of teachers in the sample was female $(\mathrm{n}=390, \%=52.4)$. In this sample, $86.2 \%$ of teachers had an undergraduate education and $13.8 \%$ had a graduate education. The ratio of new teachers was relatively lower than others. While teachers with five year seniority were $13 \%$, teachers with more than 20 years of seniority were the majority with $38.2 \%$.

\subsection{Data Collection Tools}

In this study, to determine teachers' perception of school principals' transformational leadership properties, transformational leadership scale developed by Akan, Yıldırım and Yalçın (2014) was applied. This scale was a 20-item and 5-point Likert type with definitely don't agree (1), partially don't agree (2), indecisive (3), partially agree (4) and definitely agree (5). Scale reliability of scale developed by Akan, Yıldırım and Yalçın (2014) consisting of one sub-dimension and 20-items was controlled with the Cronbach Alpha coefficient. Since the alpha coefficient of this scale was .984 , it is possible to state that this scale is reliable. Alpha reliability coefficient of this scale developed by Akan, Yıldırım and Yalçın (2014) was 0.96.

The School Safety Scale developed by Akan and Zengin (2018) was applied to measure the School Safety level. School safety scale is a measurement tool developed to determine teachers' views for school safety. School safety scale organised as participation scale was 5-point Likert type scored between 1 - I don't agree to 5 - I completely agree. This scale consists of 27 items and four sub-dimensions as "Situational", "Actional/Factual", "Precautionary" and "Intrinsic". Alpha reliability coefficient of this scale was found as 0,938 for Situational, 0,697 for Actional/Factual, 0,866 for Precautionary, 0,728 for Intrinsic dimensions and 0,821 for total scale.

\subsection{Data Analysis}

In data analysis, arithmetic average, standard deviation values were considered to determine school principals' transformational leadership properties and school safety levels. Pearson Product Moment Correlation Analysis was applied to determine relationship between Transformational Leadership Scale and School Safety Scale scores; Multilinear Regression Analysis technique was applied to determine the prediction level of Transformational Leadership Scale score for School Safety Scale scores.

\section{Findings}

This section provides findings obtained by analysing data collected from scales. There are explanations and comments on school principals' transformational leadership level averages, school safety level averages, correlation analysis between school principals' transformational leadership properties and school safety, regression analysis for effects of school principals' transformational leadership properties on school safety.

\section{School principals' transformational leadership level average}

Arithmetic average and standard deviation values of participant teachers' views for school principals' transformational leadership properties are given in Table 2. 
Table 2. School Principles’ Transformational Leadership Level Average

\begin{tabular}{llll}
\hline Variables & $\mathrm{n}$ & $\overline{\mathrm{x}}$ & ss. \\
\hline Transformational & 744 & 3.61 & 1.13 \\
Leadership Total Score & & &
\end{tabular}

When teachers' perception of school principals' transformational leadership level averages were analysed, it was seen that teachers agreed at high $(3.61 \pm 1.13)$ level to total.

\section{School safety level average}

Table 3. School safety level findings

\begin{tabular}{llll}
\hline Variables & $\mathrm{n}$ & $\overline{\mathrm{x}}$ & $\mathrm{ss.}$ \\
\hline Situational & 744 & 2.09 & 1.03 \\
\hline Actional/Factual & 744 & 1.35 & .66 \\
\hline Precautionary & 744 & 3.21 & 1.04 \\
\hline Intrinsic & 744 & 1.73 & .98 \\
\hline School Safety Total & 744 & 3.31 & .48
\end{tabular}

According to participant teachers' perceptions, in terms of school safety, situational sub-dimension was low (2.09 \pm 1.03); actional/factual sub-dimension was low (1.35 \pm .66$)$; precautionary sub-dimension was high (3.21 \pm 1.04$)$; intrinsic sub-dimension was low $(1.73 \pm .98)$; school safety total score was high $(3.31 \pm .48)$.

Correlation analysis for the relationship between school principals' transformational leadership properties and school safety based on secondary school teacher perceptions

Table 4. Correlation analysis for school principles' transformational leadership properties and school safety

\begin{tabular}{lcc}
\hline & $\begin{array}{l}\text { Transformational } \\
\text { Leadership }\end{array}$ & School Safety \\
\hline $\begin{array}{l}\text { Transformational } \\
\text { Leadership }\end{array}$ & -- & $0.102 *$ \\
\hline
\end{tabular}

${ }^{*} \mathrm{p}<0.05$

As it can be seen from the table, there was weak but positive statistically significant relationship between transformational leadership properties and school safety $(r=0.102, \mathrm{p}<0.05)$.

\section{Regression analysis for effects of school principals' transformational leadership properties on school safety}

In this section, linear regression analysis results that show effects of school principals' transformational leadership properties on school safety area presented.

Table 5. Multilinear regression analysis results for school safety level prediction

\begin{tabular}{|c|c|c|c|c|c|c|c|}
\hline Variable & B & $\begin{array}{l}\text { Std. } \\
\text { Error }\end{array}$ & $\beta$ & $t$ & $p$ & $\begin{array}{l}\text { Unbiased } \\
\mathrm{r}\end{array}$ & $\begin{array}{l}\text { Partial } \\
\mathrm{r}\end{array}$ \\
\hline Constant & 85,100 & 15.95 & & 53,356 & .000 & & \\
\hline $\begin{array}{l}\text { Transformational } \\
\text { Leadership } \\
\text { Properties }\end{array}$ & 0,059 & 0,021 & 0,102 & 2,803 & .005 & .102 & .102 \\
\hline
\end{tabular}

$\mathrm{R}=0.102 \quad \mathrm{R}^{2}=0.010=7.855 \mathrm{p}<.005$

There was significant relationship between school principals' transformational leadership properties and school safety $\left(\mathrm{R}=0,102, \mathrm{R}^{2}=0.010\right.$ and it was seen that transformational leadership properties were a significant predictor of school safety $\left[\mathrm{R}^{2}=0.010\right]\left[\mathrm{F}_{(1,742)}=7.855, p=.005<.05\right]$. Transformational leadership explains $1 \%$ of school safety. Significance test for main prediction variable coefficient of regression equation $(B=0.059)$ showed that it was a significant predictor of school safety $(p=.005<.05)$. 


\section{Discussion and Conclusion}

According to participant teachers' perception, school principals' transformational leadership properties level was at a high level for the total score. According to Şahin (2009), having an effective leader is closely related with creativity and effectively using human potential in the organisation. Karakaya (2005) expressed that transformational leaders encouraged employees to be creative and innovative and provides solutions to old or unresolved problems with new approaches. School principal as transformational leader helps solving problems to increase teachers' performance by supporting teachers. Thus, effectiveness in schools would increase. Leader should support teachers' work, increases their motivation; thus, makes them keep up with transformation society (Celep, 2004 Transferred by.,Akçakoce \& Bilgin, 2016).

To support the statement above, in study of Buluç (2009), school principal utilised well-structured reward system. These rewards should not only be considered at material reward basis. When teachers put their effort to realise expected roles and behaviours, school principals' appreciation and satisfaction towards teachers is another reward.

According to participant teachers' perception, school safety level was at low level at situational sub-dimension. When the most and least agreed statements of teachers were considered, it is possible to say that some students damage school items on purpose and there was no intentional damaging behaviour when there is usurpation, gangs and lack of control, although there are conflicts. One of the research findings of Yıldız and Sümer (2010) was that adolescents who believe themselves to live in a dangerous environment reported more frequent violent behaviour. According to Flannery (2006) being a gang member increases risk of a young person to be subjected to violence, be victim of violence, have transgressive or violent action (this might occur under pressure). It was determined that gang member youths used high level of drugs compared to non-members (Transferred by: Gül \& Güneş, 2009).

According to participant teachers' perception, school safety level was at low level at actional/factual sub-dimension. When the most and least agreed statements of teachers were considered, it is possible to say that discipline in schools is important however, there are no precautions for health problems. Osher et al. (2010) analysed three approaches to improve school discipline in their "How Can We Improve School Discipline?" study. These are: class management, supporting positive behaviour along the school, social and emotional learning. School discipline requires more than punishment. Based on this three approach, strategies and applications to increase safety provides important data to develop discipline.

According to participant teachers' perception, school safety level was at high level at the precautionary sub-dimension. When the most and least agreed statements of teachers were considered, it is possible to say that drugs are sold around schools but teachers have no information about students using drugs; however, there are students that consume alcohol and there is partial sexual harassment. Texts with threatening statements around schools and drug dealers around schools pose significant danger.

According to participant teachers' perception, school safety level was at low level at intrinsic sub-dimension. Majority of teachers agreed that there was no political discussion between students and school principal failed to ask everyone's idea when making a decision about school safety. Cooperative decisions will benefit through high-quality decisions and these decisions have a higher quality (Nyhan, 2000). Consulting with teachers during decision-making not only provides quality decisions but also increases teachers' motivation (Tschannen-Moran, 2001). Teachers' views during decision making at schools help teacher satisfaction, loyalty and adopting these decisions (Tschannen-Moran \& Hoy, 2000).

There was a weak but positive statistically significant relationship between transformational leadership properties and school safety. There are studies on the relationship between transformational leaders and school safety in the literature. Gençay (2014) analysed the relationship between school principal leadership style and school images based on high-school types and found that there was statistically significant link between transformational leadership style and organizational image perception in Anatolian high-schools. The lack of a plan to immunises against violence (Dwyer \& Osher, 2000). Göksoy, Emen and Aksoy (2013) stated that there is a dramatic increase in discipline and violence at schools and discipline and violence issues at schools were primary problems areas that school principals must solve. Turhan and Turan (2012) expressed that one of the most important responsibilities of school management is to provide and sustain a safe school environment. When individuals at schools feel safe at all directions, these individuals can realise their organizational objectives. Substance addiction, food safety, readiness for disasters, safety of physical environment, security and safety at school and traffic around school are the basis of school safety. Teachers, school principal and all personnel should work together. Can (2014) stated that school principal plays an important role to prevent existing problems that pose a threat, plan and apply precautions. Additionally, managers should be emphasised by showing leader behaviours in addition to management duties. In this sense, school principals raised as leaders in pre-service and in-service training should consider school safety as an important issue. School management should warn and educate parents and all school personnel against that safety issue can emerge at any moment. 
There was significant relationship between school principals' transformational leadership properties and school safety and it was seen that transformational leadership properties were significant predictor of school safety. Transformational leadership explains $1 \%$ of school safety. As a result of this study, it is possible to say that teachers' enthusiasm and excitement to perceive school principals' transformational leadership properties was not lively and that principles were unable to help discover methods to reach objectives and they failed to award creative ideas. Therefore, school principals should use and apply a necessary reward system to prevent conflicts in the institution and employee success in the institution. Transformational leadership assessments might be considered in school principal assignments.

In this study, it was seen that school principal were insufficient in transformational leadership. Transformational leadership is the most effective leadership to reflect charm and leadership power of school principal within the institution. School principals should have in-service training for transformational leadership. School principals should previously identify, simultaneously intervene, and correct any problem that might occur within the institution. Since there could be a school safety problem at any time and in any school, school principal, teachers, parents and other personnel should be informed pre-service and in-service training and awareness level should be increased.

\section{References}

Akan, D., \& Yalçı, S. (2015). Investigation of the relationship between school administrators 'leadership styles and teachers' organizational commitment. Journal of Education and Humanities, 6(11), 392-415.

Akan, D., \& Zengin, M. (2019). Improving the school security scale. Electronic Journal of Social Sciences, 18(70). https://doi.org/10.17755/esosder.417115

Akan, D., Yıldırım, İ., \& Yalçın, S. (2014). School principals' leadership style scale development. Electronic Journal of Social Sciences, 13(51), 392-415. https://doi.org/10.17755/esosder.28743

Akçekoce, A., \& Bilgin, K. U. (2016). Leadership styles of school principals and teacher performance. Journal of Contemporary Management Sciences, 2 (2), 1-23.

Astor, R., Guerra, N., \& Acker, R. (2010). How can we improve school safety research? Educational Researcher, 39(1), 69-78. https://doi.org/10.3102/0013189X09357619

Aydoğmuş, H. Y. (2004). Transformational leadership and an application on transformational leadership behaviors in Kayseri police department (Thesis). (Thesis No.146543)

Berber, A. (2000). The concept of transformational and interactive leadership, development and role of transformational leadership in management and organization management. Journal of Management, 11/36, 33-50.

Bucher, K. T., \& Manning, M. L. (2005). Creating safe schools. The Clearing House, 79(1), 55-60. https://doi.org/10.3200/TCHS.79.1.55-60

Buluç, B. (2009). Relationship between school principals' leadership styles and organizational commitment according to their perceptions of classroom teachers. Journal of Educational Management in Theory and Practice, 15/57, 5-34.

Can, E. (2014). Opinions of teachers and administrators working in high schools on school security (Thesis). (Thesis No.366614)

Çelik, Ö. (2010). The relationship between self-awareness and transformational leadership characteristics of school administrators (Thesis). (Thesis No.253363)

Çobanoğlu F. (2003). Transformational leadership behaviors of primary school administrators (Thesis).(Thesis No.140636)

Cömert, M. (2004). Transformational Leadership. XIII. National Educational Sciences Congress.

Dwyer, K., \& Osher, D. (2000). Safe guarding our children: an action guide. Washington, D.C.: U.S. Departments of Education and Justice, American Institutes for Research.

Erkunt, G. (2015). The effects of transformational leadership behaviors on organizational culture (Thesis). (Thesis No.393329)

Eryılmaz, F. (2006). Industrial vocational high school principals' level of transformational leadership (Thesis). (Thesis No.191126)

Furlong, M. J., \& Green, J. G. (2005). Development of the California school climate and safety survey-short form. Psychology in the Schools, 42(2), 136-149. https://doi.org/10.1002/pits.20053

Gençay, A. (2014). Leadership styles and school image of school administrators according to teachers' opinions (Thesis). (Thesis No.369282) 
Göksoy, S., Emen, E., \& Aksoy, C. (2013). Security problem in schools. Milli Eğitim Dergisi, 200(1), 123-139.

Gül, S. K., \& Güneş, İ. D. (2009). Adolescence problems and violence. http://www.acarin dex.com/

Karakaya, T. (2005). An application on the effects of transformational leadership on motivation of subordinates in organizations (Thesis). (Thesis No.256986)

Karip, E. (1998). Transformational leadership. https://pegem.net/dosyalar/dokuman/822-201202111 77 54-karip.pdf

Keleş, G. Ö. (2009). Teachers' views on the level of transformational leadership characteristics of primary school principals (Thesis). (Thesis No.235335)

Mayer J. M., \& Leone, P. E. (1999). A structural analysis of school violence and disruption: imlications for creating safer schools. Education \& Treatment of Children, 22(3), 333-356.

Memduhoğlu, H. B., \& Taşdan, M. (2008). School and student safety: a conceptual analysis. Journal of Çukurova University Faculty of Education, 3(34), 69-83.

Mestry, R. (2015). Exploring the forms and underlying causes of school-based violence: implications for school safety and security. Anthropologist, 19(3), 655-663. https://doi.org/10.1080/09720073.2015.11891700

Murat, G., \& Açıkgöz, B. (2008). Indispensable actors of the age of change: transformational leaders. Кати-İs, 10(2), 153-171.

Nyhan, R. C. (2000). Changing the paradigm trust and its role in public sector organizations. American Review of Public Administration, 30(1), 87-109. https://doi.org/10.1177/02750740022064560

Ögel,K., Tarı, I., \& Eke, C. Y. (2005). Prevention of crime and violence in schools. İstanbul:Yeniden Publication

Osher, D., Bear, G. G., Sprague, J. R., \& Doyle, W. (2010). How can we improve school discipline? Educational Researcher, 39(1), 48-58. https://doi.org/10.3102/0013189X09357618

Peterson, L. R., \& Skiba, R. (2001). Creating school climates that prevent school violence. The Clearing House, 74(3), https://doi.org/10.1080/00098650109599183

Posluoğlu, F. G. (2014). In order to determine the perception and solution ways of teachers and administrators about school security in educational institutions (Thesis). (Thesis No.355919)

Robbins, P. S., \& De Cenzo, D. A. (1998). Fundamentals of management. New Jersey: Prentice Hall International Editions.

Şahin, B. (2009). The role of transformational leaders in achieving organizational development. Dokuz Eylul University Journal of the Institute of Social Sciences, 11(3), 97-118.

Şahin, S. (2004). Relations between school principals' transformational and versionist leadership styles and school culture. Educational Sciences in Theory and Practice, 4(2), 365-396.

Serinkan, C. (2003). The relationship between total quality management and transformational leadership and a research conducted in Denizli region (Thesis). (Thesis No.140717)

Temel, E. (2016). The mediating role of organizational identification in the relationship between transformational leadership and psychological empowerment: an application in public institutions in Nazilli (Thesis). (Thesis No.421773)

Tschannen-Moran, M. (2001). Collaboration and the need for trust. Journal of Educational Administration, 39(4), 306-331. https://doi.org/10.1108/EUM0000000005493

Tschannen-Moran, M., \& Hoy, W. (2000). A Multidisciplinary analysis of the nature, meaning and measurement of trust. Review of Educational Research, 70(4), 547-593. https://doi.org/10.3102/00346543070004547

Yıldız, E. Ç., \& Sümer, Z. H. (2010). Environmental risk, environmental safety and school climate perception in predicting aggressive behavior. Turkish Journal of Psychological Counseling and Guidance, 4(34), 161-173.

Zeren, H. (2007). The relationship between the transformational leadership styles of primary school principals and the organizational commitment of the teachers in this school (Thesis). (Thesis No.214327)

\section{Copyrights}

Copyright for this article is retained by the author(s), with first publication rights granted to the journal.

This is an open-access article distributed under the terms and conditions of the Creative Commons Attribution license which permits unrestricted use, distribution, and reproduction in any medium, provided the original work is properly cited. 